\title{
O TRIBUNAL CONSTITUCIONAL E O EXERCÍCIO DA FUNÇÃO LEGISLATIVA STRICTO SENSU PARA A EFETIVAÇÃO DOS DIREITOS FUNDAMENTAIS EM DECORRÊNCIA DE UMA OMISSÃO LEGISLATIVA INCONSTITUCIONAL
}

\author{
THE CONSTITUTIONAL COURT AND THE \\ EXERCISE OF LEGISLATIVE FUNCTIONS \\ STRICTO SENSU FOR THE ENFORCEMENT OF \\ FUNDAMENTAL RIGHTS AS A RESULT OF AN \\ UNCONSTITUTIONAL LEGISLATIVE OMISSION
}

Anderson Sant Ana Pedra*

\begin{abstract}
RESUMO
O Tribunal Constitucional não mais restringe sua atuação como mero "legislador negativo", exercendo também a função legislativa stricto sensu a fim de suprir eventuais omissões legislativas inconstitucionais decorrentes da inércia do titular da função de legislar. Tal atuação deve ocorrer principalmente quando o que está em jogo é a efetividade de direitos fundamentais, assumindo, então, o Tribunal Constitucional, de forma provisória, o exercício da função legislativa.
\end{abstract}

Palavras-chave: Omissão legislativa inconstitucional. Direitos fundamentais. Tribunal Constitucional.

\footnotetext{
Doutor em Direito do Estado pela PUC-SP; mestre em Direito pela Faculdade de Direito de Campos-RJ; especialista em Direito Público pela Consultime/Cândido Mendes; bacharel em Direito pelo Centro Universitário de Vila Velha; professor de Direito Constitucional da Faculdade de Direito de Vitória (FDV); procurador do Estado do Espírito Santo; coordenador acadêmico da Escola Superior da Procuradoria-Geral do Espírito Santo (PGEES). Contato: aspedra@ig.com.br
} 


\begin{abstract}
The Constitutional Court no longer restricts its role as a mere "negative legislator" also exercising the legislative function stricto sensu in order to supply any omissions resulting from the unconstitutional legislative inertia of the holder of the function of legislating. Such action should occur especially when what is at stake is the effectiveness of fundamental rights, then assuming the Constitutional Court, on a provisional basis, the exercise of legislative functions.
\end{abstract}

Keywords: Unconstitutional legislative omission. Fundamental Rights. Constitutional Court.

\title{
INTRODUÇÃO
}

Os direitos fundamentais não foram forjados para serem descumpridos, para serem desconsiderados pelo legislador que, por vezes, mantém-se inerte negando a eficácia que esses direitos requerem. Os direitos fundamentais devem ser conhecidos, obedecidos e implementados por todos - sociedade e Estado.

Os Tribunais Constitucionais, como garantidores do elo constitucional da sociedade, não devem se ater, apenas, ao exercício do controle de constitucionalidade stricto sensu, afastando do ordenamento jurídico aqueles atos considerados inconstitucionais. Referidas Cortes devem ir além e atuar em todas as dimensões de um verdadeiro curador da Constituição, buscando a efetivação de todas as normas constitucionais, principalmente aquelas que tutelam direitos fundamentais e que, por vezes, permanecem em estado de latência em face de uma omissão normativa inconstitucional.

Os Tribunais Constitucionais, inclusive o nosso Supremo Tribunal Federal (STF), vêm exercendo outras funções que não apenas a de mero defensor da Constituição e, além disso, vêm sendo reconhecidos como um autêntico "poder político", exercendo, inclusive, uma função legislativa stricto sensu, preenchendo espaços normativos do ordenamento jurídico infraconstitucional de modo a permitir a plena eficácia dos direitos fundamentais. 
O Tribunal Constitucional e o exercício da função legislativa stricto sensu para a efetivação dos direitos fundamentais em decorrência de uma omissão legislativa inconstitucional

Recentemente, o STF deu uma importante "guinada interpretativa" no instituto do mandado de injunção, ao determinar que o direito fundamental à greve no serviço público fosse regrado, no que couber, pela legislação pertinente à do setor privado - refiro-me aqui aos Mandados de Injunção n $^{\text {os }}$ 670-ES e 712/PA.

Nesse contexto, é necessário investigar se a atuação do Tribunal Constitucional, ao exercer uma função legislativa stricto sensu para conferir eficácia a direitos fundamentais, é (in)ofensiva à cláusula da separação de poderes, e de que forma essa atuação pode ocorrer para suprir uma omissão legislativa inconstitucional, deslocando para o Tribunal a legitimidade para atuar como "legislador positivo" (órgão de normação positiva).

\section{A CLÁUSULA DA SEPARAÇÃO DE PODERES}

\section{SEPARAÇÃO DE PODERES OU DISTRIBUIÇÃO DE FUNÇÕES ENTRE ÓRGÃOS CONSTITUCIONAIS}

O que, geralmente, embora de forma equivocada, é muitas vezes designado como a separação dos poderes do Estado é, na verdade, a distribuição de determinadas funções estatais a diferentes órgãos.

Não diferente, Kelsen prefere a terminologia "distribuição" no lugar de "separação", justamente para que não se desenvolva a equivocada ideia de que uma separação busca uma segregação, um isolamento de cada uma das funções. O objetivo da separação é outro; é permitir um controle mútuo dos "poderes". ${ }^{1}$

Ao analisar as expressões "distribuição" e "separação" nos contornos acima delineados, não resta dúvida de que a expressão "distribuição de funções estatais" se mostra mais adequada, contudo não é equivocada a utilização da expressão "separação de poderes", desde que reste assentado que a expressão não está a externar um isolamento de cada uma das funções.

Talvez pela imprecisão terminológica mencionada, as Constituições, em geral, não contêm dispositivo especial sobre a cláusula da separação de poderes decorrendo esta de enunciados normativos 
esparsos, nos quais as funções estatais são distribuídas aos respectivos órgãos constitucionais de soberania.

Enquanto se mantiver a cláusula da separação de poderes como supedâneo do esquema de organização de poderes num determinado Estado (cláusula parâmetro), impõe-se manter a delimitação de zonas de atuação independentes e harmônicas dos órgãos constitucionais de soberania, definidos como aqueles órgãos

[...] (1) cujo status e competência são imediata e fundamentalmente 'constituídos' pela constituição; (2) dispõem de um poder de auto-organização interna; (3) que não estão subordinados a quaisquer outros; (4) que estabelecem relações de interdependência e de controlo em relação a outros órgãos igualmente ordenados na e pela constituição [...]. Não basta, pois, que eles sejam 'mencionados' na constituição; as suas competências e funções devem resultar, no essencial, da lei fundamental. ${ }^{2}$

A cláusula da independência entre os "poderes" também emerge da Constituição. Afinal, só é possível cogitar em "poderes" independentes quando as respectivas competências estão elencadas na Constituição.

Contudo, em geral, as Constituições não contêm enunciados normativos específicos quanto à distribuição de poderes, preferindo utilizar de disposições esparsas, nas quais se declara que o Poder Executivo será exercido pelo chefe de Estado/Governo, o Legislativo pelo Congresso, e o Judiciário pelos Tribunais Superiores e a magistratura em geral.

Apenas a título de exemplificação, a Constituição brasileira de 1988 não desenhou nenhum tratamento sistemático das funções estatais, preferindo apenas proceder à consagração da cláusula da separação de poderes, prescrevendo, em seu art. $2^{\circ}$, que "São poderes da União, independentes e harmônicos entre si, o Legislativo, o Executivo e o Judiciário".

A exegese desse dispositivo foi construída no direito constitucional brasileiro buscando, basicamente, inspiração na teoria de Montesquieu, sem realizar uma crítica dessa tradicional teoria que não mais vem se mostrando eficiente nos Estados modernos, inclusive no Brasil. 
O Tribunal Constitucional e o exercício da função legislativa stricto sensu para a efetivação dos direitos fundamentais em decorrência de uma omissão legislativa inconstitucional

Além da referência do art. $2^{\circ}$ da Constituição da República Federativa do Brasil (CRFB), há uma articulação dispersa no texto constitucional e uma orientação funcional do que corresponderá a cada um desses órgãos. Apenas após um estudo aprofundado e sistemático é que se poderá chegar a uma conclusão sobre as funções que devem exercer cada um dos órgãos constitucionais de soberania previstos na Constituição brasileira de 1988.

Cumpre registrar que, talvez com o intuito de evitar um sentido de "separatismo" e também expressões como "divisão" ou "distribuição de poderes", fez bem o legislador constituinte brasileiro ao mencionar apenas a expressão "independentes e harmônicos entre si" no art. $2^{\circ}$ da CRFB.

\section{A CLÁUSUlA DA SEPARAÇÃO DE PODERES ALÉM DA TRIPARTIÇÃO E DA SEPARAÇÃO ABSOLUTA}

Não se objetiva aqui fazer um inventário das críticas dirigidas contra a clássica teoria da separação de poderes. Afinal, é inquestionável que a cláusula da separação de poderes foi e é uma boa ideia, contudo não há nenhuma razão para supor que os pensadores clássicos esgotaram a sua excelência. Obviamente, os detalhes do contexto das épocas pretéritas diferenciam-se do atual momento, porém os problemas, os interesses, os dilemas são, na essência, os mesmos que se têm atualmente. ${ }^{3}$

Uma nova leitura da cláusula da separação de poderes, em um sentido político de equilíbrio, permitirá a busca de novas soluções aos atuais problemas da sociedade e do Estado e, nessa marcha, importa trazer respostas para a necessidade de realizar os fins que o Estado deve perseguir - como a efetivação de direitos fundamentais, por meio das funções que deve exercer por intermédios dos órgãos constitucionais de soberania estabelecidos constitucionalmente.

O conceito de separação de poderes é histórico. A separação de poderes não é um fim em si mesma, mas um meio e instrumento de realização de valores essenciais de convivência humana, que se traduzem basicamente nos direitos fundamentais do homem. A separação de poderes não é mero conceito político, abstrato e estático, mas sim 
um processo de afirmação do povo, de garantia e de plena eficácia dos direitos fundamentais que o povo foi e vai conquistando no decorrer da história, variando de maneira considerável as posições doutrinárias acerca do que se há de entender por separação de poderes.

Além da ausência de padrão acerca da previsão constitucional quanto à cláusula da separação de poderes e das críticas a tal cláusula, inexiste, também, como já dito aqui, um conceito apriorístico sobre a cláusula da separação de poderes.

É inquestionável que, em decorrência da multiplicidade de elementos políticos, sociais e econômicos em jogo na sociedade moderna, a teoria tripartida da separação de poderes se mostra excessivamente reducionista. ${ }^{4}$

Também não se pode olvidar que a transição do Estado Liberal para o Estado Social provocou uma alteração no panorama das decisões políticas. A decisão política foi postergada para o momento da concretização da lei pelo Estado (administrador ou juiz), produzindo, assim, uma importante alteração no eixo da cláusula da separação de poderes, já que gerou (in)diretamente um fortalecimento do Executivo diante da necessidade de implementar as demandas do Welfare State, bem como fortalecer o Judiciário, decorrente da sua inevitável politização na medida em que, ao interpretar a lei, com cláusulas gerais e principiológicas, o juiz acaba por decidir politicamente, tudo isso à margem do Legislativo até então com mais destaque entre os "poderes" estatais em face à importância da lei.

Além da imprecisão conceitual e substancial, são também grandes as dificuldades decorrentes da distribuição de poderes - complexidade da sociedade e do Governo, morosidade no exercício das funções estatais, conflitos explícitos e/ou implícitos entre as competências dos órgãos constitucionais de soberania - contudo não se pode esquecer daquilo que a história já registrou: as consequências da concentração do poder são desastrosas, sendo melhor a existência de uma cláusula de separação de poderes, mesmo que confusa e ineficiente, do que a inexistência de tal cláusula. Deve restar claro que a cláusula da separação de poderes permanece absolutamente válida e necessária na sua essência, afinal, qualquer concentração de poder se torna uma ameaça aos direitos fundamentais. 
O Tribunal Constitucional e o exercício da função legislativa stricto sensu para a efetivação dos direitos fundamentais em decorrência de uma omissão legislativa inconstitucional

Na busca da implementação de direitos fundamentais, mostra-se indesejável uma separação absoluta dos poderes em face da unidade do poder político e da finalidade principal (ou existencial) do Estado (justiça, segurança e bem-estar). ${ }^{5}$ De igual modo é indispensável uma ligação orgânica, de colaboração e compreensão entre os órgãos do Estado.

Malberg excluiu a construção clássica de poderes separados, estanque e igualmente soberanos, considerando, com algum sarcasmo, que a separação de poderes só pode ser aplicável na medida em que não pressuponha uma separação verdadeira e efetiva, pois uma afetação exclusiva de cada uma das funções a um órgão estatal determinado é algo completamente irrealizável. ${ }^{6}$ Conclui ainda o autor afirmando que, em Direito, não é a classificação racional e preconcebida das funções que determina a competência dos órgãos, mas, pelo contrário, é a competência dos órgãos o que determina a distinção jurídica das funções. ${ }^{7}$

De igual modo, Duguit rejeita a cláusula da separação de poderes concebida como uma separação rígida e absoluta de poderes, como um teorema geométrico, pois tal concepção não se coaduna com a realidade em que se observa uma atuação cooperada dos poderes, bem como se nota, por vezes, a subordinação de um poder a outro. ${ }^{8}$

Não há mais lugar para uma rígida separação de poderes, conforme defendido por muitos, pois tal cláusula, tão cara aos liberais, necessita de um processo de transformação, já que o Estado contemporâneo não aceita mais a rigidez da separação de poderes, até porque essa separação rígida só "fortalece" os poderes (órgãos), deixando de lado o cidadão - ator principal de uma Constituição - com seus direitos fundamentais. A separação de poderes deve ser pensada não como uma visão do Poder em si mesmo, mas sim como um instituto protetivo do cidadão e que, concomitantemente, pela especialidade no exercício das funções, permite ao Estado cumprir melhor suas finalidades.

Nessa linha, Kelsen afirma que a significação histórica da cláusula da separação de poderes se encontra precisamente no fato de que ela opera antes contra uma concentração do que a favor de uma separação. ${ }^{9}$

Pode-se, então, afirmar que a doutrina da separação de poderes age atualmente como técnica de organização da estrutura política do Estado, distribuindo as funções estatais, de forma não exclusiva, 
por diversos órgãos constitucionais de soberania, permitindo ainda o controle recíproco.

Nesse viés, Piçarra, ao lecionar sobre novas abordagens da cláusula constitucional da separação de poderes, traz:

Ganha progressiva importância na actualidade o entendimento do princípio da separação dos poderes como princípio de organização óptima das funções estaduais, cujo contributo tem sido significativo para a determinação do seu valor normativo.

Ele vai no sentido de precisar a capacidade do princípio para fornecer critérios de solução quanto à exacta delimitação de competências entre os órgãos constitucionais, sobretudo em casos tão problemáticos como o direito judicial, o controlo jurisdicional da discricionariedade administrativa e dos vários tipos da chama discricionariedade imprópria, a inconstitucionalidade por omissão e o instituto dos assentos. ${ }^{10}$

Nesse prisma, a cláusula da separação de poderes não veda a prática, por um órgão constitucional de soberania, de funções que pela sua natureza essencial pertença a outro. A correta formulação da mencionada cláusula consiste em afirmar que a um órgão constitucional de soberania é lícito, constitucionalmente, exercer qualquer função, independentemente da sua natureza, desde que assim prescreva a Constituição.

A soberania estatal atribui à Constituição a "competência para distribuição das competências" entre os órgãos constitucionais de soberania, uma vez que somente o Poder Constituinte pode defini-las e dimensioná-las para então estabelecer a sua repartição.

Como bem salienta Silva, ao discorrer sobre a supremacia da Constituição, "[...] todos os poderes estatais são legítimos na medida em que ela [Constituição] os reconheça e na proporção por ela distribuídos" ${ }^{11}$

A cláusula da separação de poderes se apresenta, assim, como uma teoria de estruturação organizacional para cada Estado, estabelecida pela respectiva Constituição.

Não há hoje, em muitos países do mundo, correspondência entre os órgãos estatais instituídos constitucionalmente e as funções do Estado que a teoria clássica define, afinal a um órgão constitucional de soberania pode ser atribuída competência relativa a outras funções jurídicas do Estado. 
O Tribunal Constitucional e o exercício da função legislativa stricto sensu para a efetivação dos direitos fundamentais em decorrência de uma omissão legislativa inconstitucional

Mas que fique claro que as exceções à cláusula da separação de poderes, ou seja, todo o exercício de competência de cada órgão constitucional de soberania (poder), a título secundário, em funções que teórica e originariamente competiriam a outro poder, só serão admissíveis quando a Constituição as prescrever, e nos termos, condições e limites que ela estabelecer.

Pode-se, então, afirmar que compete à Constituição efetuar a especificação das funções e a distribuição das competências entre os órgãos constitucionais de soberania (poderes) de forma a atender, em maior ou menor grau, à especialidade das funções estatais, considerando para tanto a necessidade de se ter uma estrutura política equilibrada a fim de garantir a liberdade do indivíduo, possibilitar uma eficiência estatal e implementar os direitos fundamentais.

O Tribunal Constitucional pode, e deve, ser o curador dos direitos fundamentais, mas ele não é o único com tal mister. A Constituição deve atribuir competência para àqueles órgãos que irão desenvolver a mais importante função dentro de uma democracia - legislar (lato sensu). Cabe à Constituição definir qual(is) órgão(s) poderá(ão) exercer a função legislativa (lato sensu), e quando poderá assim atuar, sob pena de ocorrer uma sobreposição de atos normativos com o mesmo fim - a curadoria dos direitos fundamentais, além da possibilidade de ocorrer uma desarmonia na estrutura estatal, tendo em vista que a atuação de um órgão poderá interferir, indevidamente, na competência de outro órgão.

\section{A NECESSIDADE DE EFETIVAÇÃO DOS DIREI- TOS FUNDAMENTAIS}

\section{A FORÇA NORMATIVA DOS ENUNCIADOS NOR- MATIVOS CONSTITUCIONAIS}

A força normativa da Constituição está intrinsicamente ligada à existência de um, ou mais de um, órgão constitucional de soberania com a competência de defender e efetivar seu texto.

O direito constitucional é também direito positivo. Nesse sentido, fala-se na "Constituição como norma", 12 na "força normativa da 
Constituição"13 e na "Constituição como fonte de Direito, devendo como tal ser tomada e utilizada na sua totalidade" ${ }^{14}$

Força normativa da Constituição ou normatividade da Constituição são expressões que significam que a Constituição é uma lei vinculativa dotada de efetividade e aplicabilidade. A força normativa da Constituição visa a exprimir, muito simplesmente, que a Constituição, sendo uma lei, como lei, deve ser aplicada. Afasta-se, assim, a tese generalizante aceita nos fins do século XIX e nas primeiras décadas do século XX que atribuía à Constituição um "valor declaratório", "uma natureza de simples direção política"; um caráter programático despido de força jurídica. ${ }^{15}$ Uma importante mudança de paradigma ao longo do século XX foi, sem dúvida, a atribuição à norma constitucional do status de norma jurídica.

Ombreia-se aqui, com as lições de Bidart Campos, no sentido de que sempre é possível afirmar que a força normativa é uma característica indispensável da Constituição, num primeiro momento, para manter a coincidência entre a Constituição escrita e a realidade, num segundo, para lograr a alteração que a Constituição pretende obter no deslocamento da realidade divergente. ${ }^{16}$

Bem sintetiza Hesse, em seu clássico estudo acerca da força normativa da Constituição:

[...] [a] constituição não configura, portanto, apenas expressão de um ser, mas também de um dever ser; ela significa mais do que o simples reflexo das condições fáticas de sua vigência, particularmente as forças sociais e políticas. Graças à pretensão de eficácia, a constituição procura imprimir ordem e conformação à realidade política e social. ${ }^{17}$

Diante dessas afirmações, não se pode mais permitir a postergação da aplicabilidade e eficácia de qualquer norma do direito constitucional, notadamente aquelas que cuidam de direitos fundamentais, afinal, o direito é o instrumento pelo qual se faz da palavra vida; e, na vida, a Justiça. É como o padre que transforma, pelo milagre da transubstanciação, o pão em Corpo de Cristo - "Eis o mistério da fé"; 18 - o intérprete constitucional deve transformar, pelo milagre da vivificação da palavra, o verbo em vida - eis o desafio da jurisdição constitucional. 
O Tribunal Constitucional e o exercício da função legislativa stricto sensu para a efetivação dos direitos fundamentais em decorrência de uma omissão legislativa inconstitucional

Embora resultante de um impulso político, que deflagra o Poder Constituinte originário, a Constituição, uma vez posta em vigência, é um documento jurídico e, sendo um conjunto de normas jurídicas, tem caráter imediato e prospectivo; e não são essas normas meras opiniões, meras aspirações ou plataforma política, até porque, em nível lógico, nenhuma lei, independentemente da sua hierarquia, é editada para não ser cumprida. ${ }^{19}$

Häberle bem destaca que "[...] [o] Estado constitucional pretende que seus textos sejam realizados, que se cumpram 'socialmente'; 'reivindica' a realidade para si: sua 'normatividade' deve converter-se em 'normalidade'". 20

Cumpre lembrar que a eficácia de uma Constituição dependerá não só da sua fidelidade aos valores sociais e políticos consagrados pela sociedade, mas também - e principalmente - de uma correta interpretação daquilo que o Texto Constitucional prescreve.

Como bem anota Alexy, as Constituições modernas dão aos direitos fundamentais, por regra, a força de concretização suprema, e, quando elas não o fazem, deveriam ser interpretadas nesse sentido. ${ }^{21}$

Assim, cabe desmistificar a Constituição, concedendo-lhe a sua dignidade para que os seus enunciados, mormente aqueles que prescrevem direitos fundamentais, tenham eficácia e aplicabilidade, não mais permitindo que a vontade constitucional fique aprisionada pela omissão legislativa (normativa) inconstitucional. Verificada uma omissão legislativa, deve o Tribunal Constitucional atuar como órgão de normação positiva, desempenhando, assim, não só seu papel de defensor da Constituição e dos direitos fundamentais, mas também de curador.

\section{TRIBUNAL CONSTITUCIONAL COMO CURADOR DOS DIREITOS FUNDAMENTAIS}

A classificação de um sistema político como democrático constitucional depende da existência de efetivas instituições por meio das quais o exercício do poder político esteja distribuído entre os detentores do poder, e que também os detentores do poder estejam submetidos ao controle dos destinatários do poder. ${ }^{22}$ 
O que está a se desenvolver neste trabalho é relacionado com o Tribunal Constitucional na sua atuação não como um mero defensor ou protetor de direitos fundamentais, mas sim como seu curador, ${ }^{23}$ valendo-se de outras funções que não apenas aquela idealizada primeiramente por Kelsen - a do controle de constitucionalidade: legislador negativo atuando na defesa da Constituição.

A expressão "defesa da Constituição" já não mais traduz fielmente - ou na íntegra - o conjunto de atividades desenvolvidas pelos Tribunais Constitucionais, ao menos no sentido de que sua atuação ocorre exclusivamente quando houver um "ataque" à Constituição. Afinal, haverá situações em que a atuação do Tribunal deverá ocorrer não apenas de forma negativa, mas, também, positivamente, de modo a prestigiar o crescimento do sentimento constitucional e a implementação dos direitos fundamentais.

Não se nega que a Constituição permite ao legislador, por vezes, escolher o tempo e as circunstâncias da sua intervenção, bem como determinar ou densificar o seu conteúdo; contudo, devem-se respeitar os fins, os valores e os critérios constitucionais estabelecidos pelo Poder Constituinte originário.

A discricionariedade da atuação concedida ao legislador não pode conduzir a um descumprimento ou a uma ineficácia dos direitos fundamentais. Diante de situações como essas, é necessário o Tribunal Constitucional emergir com uma atuação positiva e incisiva a fim de homenagear a força normativa que é inerente a tais direitos.

Um direito fundamental não pode ficar indefinidamente à mercê da boa vontade do legislador para ter sua eficácia vivificada, não pode ser corroído com comportamentos contrários aos seus modais deônticos.

A eficácia de tais enunciados certamente depende de fatores objetivos, cuja ausência ou deficiência não permite seu atingimento. Para tanto, deve o Tribunal Constitucional agir como instituição exemplar da razão pública, evitando que a eficácia ótima dos direitos fundamentais seja postergada por um comportamento omissivo de uma maioria transitória ou, ainda, por uma minoria bem organizada e posicionada.

Não se pode olvidar que o exercício da curadoria dos direitos fundamentais deverá ter um caráter eminentemente objetivo, próprio 
O Tribunal Constitucional e o exercício da função legislativa stricto sensu para a efetivação dos direitos fundamentais em decorrência de uma omissão legislativa inconstitucional

de um controle (processo) objetivo, devendo o Tribunal Constitucional desconsiderar qualquer vontade subjetiva do legislador e se ater apenas à situação factual da necessidade de efetivar os direitos fundamentais.

Como bem destaca Bidart Campos, o espaço de atuação dado pela Constituição aos órgãos estatais não permite que as competências sejam mal usadas, ou não exercidas, de forma a debilitar qualquer direito fundamental, postergar discricionariamente seu desenvolvimento, seu cumprimento ou sua aplicação, privando-a de funcionalidade ou coisa semelhante. ${ }^{24}$

O conceito de democracia não pode ser reduzido a um mero procedimento de escolha de representantes, nem à identidade entre votantes da maioria ou da opinião pública com a vontade de todos a "vontade geral" rousseauniana. "A vitória eleitoral não importa a escravidão silenciosa dos derrotados, nem se pode confundir com a apuração momentânea e circunstancial de uma opinião pública, sem apoio em reflexões e debates suficientemente informados" ${ }^{25}$

Em decorrência de uma omissão legislativa em efetivar os direitos fundamentais (de uma maioria ou de uma minoria), deve o Tribunal Constitucional utilizar mecanismos eficazes para implementá-los, e o que aqui se está a pesquisar é a atuação do Tribunal como órgão de normação positiva a fim de exercer a curadoria desses direitos.

Como bem anota Clève, "[...] inconstitucionalidade e fiscalização de inconstitucionalidade" não se confundem, já que a última só guarda sentido quando o sistema atribui "[...] uma certa conseqüência (sanção) ao ato normativo violador da Constituição. Se a norma viciada não desafia a emergência de um mecanismo sancionatório (censura), então não há razão para a fiscalização de inconstitucionalidade", até porque o principal mecanismo de efetivação da Constituição consiste na fiscalização da constitucionalidade, e essa só ocorrerá se a própria Constituição atribuir a um ou mais órgãos competência para exercitá-la. ${ }^{26}$

Como dito, a terminologia "curador" procura conjugar as ideias fundamentais de o Tribunal Constitucional ser, mais que um "defensor" dos direitos fundamentais, também um implementador, realizando-os, aplicando-os, efetivando-os ou exigindo seu cumprimento, independentemente da causa da sua ineficácia. 


\section{OS DIREITOS FUNDAMENTAIS E OCORPUS CONS- TITUCIONAL}

O reconhecimento de novos princípios, textos normativos e costumes constitucionais, além da Constituição formal, como parâmetros para o exercício da jurisdição constitucional, constitui, sem dúvida, prática eficiente no sentido do seu adensamento e consequente politização do seu exercício, destacando ainda que a quantidade e a complexidade dos parâmetros adotados para o exercício da jurisdição constitucional são diretamente proporcionais à extensão das competências dos órgãos (Judiciário e/ou Tribunal Constitucional) aptos para este exercício.

Como bem destaca Sospedra, o Direito constitucional escrito pode ser formado por uma Constituição codificada que reúne a maioria das normas constitucionais escritas e dos direitos fundamentais, porém não necessariamente sua totalidade, pois é possível que se tenha Direito constitucional e também direitos fundamentais escritos que não estejam na Constituição codificada (Código Constitucional), como no caso em que emendas à Constituição não se integram à Constituição codificada, ou quando a Constituição admita a figura das "leis constitucionais" ${ }^{27}$

Verifica-se, assim, que é possível que, em alguns países, o parâmetro para a jurisdição constitucional estenda-se a outros diplomas normativos, como notadamente na França, ${ }^{28}$ em que se concebe a figura do bloco de constitucionalidade e, em menor grau, e com uma estrutura mais complexa, na Espanha. ${ }^{29}$

Para Agra:

Bloco de constitucionalidade são princípios, contidos ou não na Carta Magna, que compartilham a mesma idéia de Constituição material, unidos por um mesmo núcleo valorativo, agasalhando a percepção de ordem constitucional global. Os franceses o denominam de bloc de constitucionnalité, os espanhóis, de bloque de la constitucionalidad e os americanos, de block of constitutionality. ${ }^{30}$

Já Canotilho anota que alguns países adotam "[...] leis com valor constitucional ao lado da Constituição". Aí a disciplina de certas matérias é realizada por meio de leis com força constitucional. ${ }^{31}$ 
O Tribunal Constitucional e o exercício da função legislativa stricto sensu para a efetivação dos direitos fundamentais em decorrência de uma omissão legislativa inconstitucional

Há, ainda, outros países que atribuem nível constitucional aos tratados internacionais, sobretudo aos que versam sobre direitos humanos.

Aqui, no Brasil, é inquestionável que, com o advento da Emenda Constitucional $n^{\circ} 45 / 2004$, que introduziu o $\S 3^{\circ}$ ao art. $5^{\circ}$ da CRFB, ${ }^{32}$ os Tratados Internacionais de Direitos Humanos aprovados com força (procedimento especial) de emenda constitucional, configurarão, para todos os efeitos, parâmetro para o controle de constitucionalidade. ${ }^{33}$

Importa salientar ainda que podem "[...] ocorrer que as prescrições constitucionais venham a encontrar sua máxima efetividade a partir de normas internacionais". ${ }^{34}$

Ao pesquisar sobre a jurisdição constitucional na Alemanha e fixar parâmetros para o controle abstrato de normas, trouxe Mendes as seguintes lições que podem ser inseridas no que aqui se intitula de "corpus constitucional":

O conceito de Lei Fundamental não se limita às disposições singulares do direito constitucional escrito. De um lado, essa idéia abrange todos os princípios constantes do texto constitucional. Por outro, esse conceito abarca, igualmente, todos os princípios derivados da Constituição enquanto unidade, tais como o princípio da democracia, o princípio federativo, o princípio da fidelidade federativa, o princípio do Estado de Direito, o princípio da ordem democrática e liberal e o princípio do estado social. ${ }^{35}$

Destaca-se, também, que, como parâmetro para o exercício da curadoria dos direitos fundamentais pelo Tribunal Constitucional, dever-se-á considerar, não só a "[...] letra do texto, mas, também, ou mesmo preponderantemente, o 'espírito' do dispositivo invocado", 36 "[...] em seus significados mais profundos e em seu verdadeiro alcance". ${ }^{37}$ Tudo isso sem se esquecer do "[...] conselho de Black de que o espírito deve estar presente na lêtra", ${ }^{38}$ sem querer, obviamente, reduzir a interpretação dos direitos fundamentais à técnica gramatical, que se apega às palavras, até porque a forma é sempre defeituosa como expressão do pensamento.

Nesse corpus constitucional também se inserem os "costumes complementares" que decorrem da interpretação da Constituição, a 
partir do seu silêncio, e que "[...] passam a integrar, fazer corpo com a Constituição escrita". 39

Bidart Campos afirma que o costume ("direito espontâneo" ou "direito constitucional informal"), cujas normas não estão formuladas por escrito, é indubitavelmente uma fonte constitucional. ${ }^{40}$

Em poucas esferas jurídicas tem o costume uma importância tão considerável qualitativamente como no Direito constitucional, ${ }^{41}$ até porque é pouco o que se pode saber do Direito constitucional de um determinado Estado, caso o estudo se circunscreva apenas aos textos escritos. ${ }^{42}$

A existência de uma Constituição formal não determina a sua exclusividade,

[...] determina, (parafraseando HELLER), a primazia da normatividade constitucional. O que a Constituição formal implica não é a proibição de normas constitucionais criadas por outra via que não a legal; é que tais normas se lhe refiram, nela entronquem e formem com ela, e sob sua égide, uma incindível contextura sistemática.

A esta luz, quando se estipula que o poderé exercido nos termos da Constituição, tem de se entender que Constituição abrange, em primeiro lugar, a Constituição formal escrita e, em segundo lugar, as normas consuetudinárias que, de diversos modos, a venham completar. Constituição é tudo e é essa Constituição que os órgãos do poder têm de acatar. ${ }^{43}$

Nesse sentido, Heller, que distingue "[...] a Constituição não normada [normalidade] e a normada [normatividade] e, dentro desta, a normada extrajuridicamente e a que o é juridicamente". Também afirma que a "Constituição normada consiste em uma normalidade da conduta normada juridicamente, ou extrajuridicamente pelo costume [e que] as normas constitucionais, tanto jurídicas como extrajurídicas, são, ao mesmo tempo que regras empíricas de previsão, critérios positivos de valorização do trabalho", pois "[...] também se rouba e se assassina com regularidade estatisticamente previsível sem que, nesse caso, a normalidade se torne normatividade" ${ }^{4}{ }^{4}$

Apesar do entendimento contrário de alguns, ${ }^{45}$ a maioria admite o costume como fonte do Direito constitucional, ${ }^{46}$ nas modalidades secundum constitutionem e praeter constitutionem. 
O Tribunal Constitucional e o exercício da função legislativa stricto sensu para a efetivação dos direitos fundamentais em decorrência de uma omissão legislativa inconstitucional

Registra-se que, em virtude da dificuldade de distinção, bem como da desnecessidade desta para o que se pretende neste trabalho, equiparar-se-ão as convenções constitucionais aos costumes constitucionais, afinal, consoante leciona Guastini, “[...] não é fácil traçar concretamente uma linha de demarcação entre normas consuetudinárias e regras convencionais". ${ }^{47}$

Canotilho anota que existirá uma norma constitucional consuetudinária "[...] quando no sistema jurídico constitucional se verifica a institucionalização social de um acto ou facto aos quais é reconhecida a significação de uma norma de caráter constitucional", 48 sendo desnecessária a forma escrita, já que se trata da manifestação da própria consciência da sociedade.-

Um fator que serve de justificativa para a aceitação do costume constitucional no alargamento do corpus constitucional para a curadoria dos direitos fundamentais, juntamente com leis constitucionais, tratados internacionais, é o fato de o sistema constitucional ser aberto, “[...] no qual se poderão desenvolver usos institucionais, isto é, actos ou factos materiais compreendidos como comportamentos juridicamente vinculativos" ${ }^{\prime} 9$

Cobra relevo consignar que a verificação de costumes constitucionais não é exclusivo de um sistema com Constituição costumeira e flexível. Ferraz afirma que o costume constitucional é perfeitamente compatível com a noção de Constituição escrita e rígida, já que

[...] [o] fundamento primeiro da existência do costume constitucional encontra-se no próprio poder constituinte que, dotado de caráter de permanente, não se esgota em sua obra - a Constituição - mas conserva-se latente, quando expressamente previsto, sob a forma do poder de reforma constitucional. Por outro lado, continua latente também, de modo não previsto e não organizado no chamado poder constituinte difuso, invisível, que intervém quando necessário para preencher lacunas ou interpretar disposições constitucionais obscuras. Esse poder constituinte difuso é atuado pelos órgãos constitucionais que têm competência para aplicar normas constitucionais e que, mesmo diante da obscuridade do texto, precisam interpretá-lo para dar-lhe aplicação. É também posto em ação por esses mesmos poderes quando há na Constituição vazios, espaços em branco, que somente normas de natureza constitucional poderiam preencher e não o fazem. Nessas hipóteses, os poderes 
constitucionais têm o dever de atuar a Constituição, já que a situação, o comportamento ou o ato, que por ela deveriam ser regidos e não o são, devem encontrar resposta ou solução. ${ }^{50}$

Assim, quando se fala em curadoria dos direitos fundamentais para o que interessa o presente estudo, além do texto constitucional, do seu significado mais profundo extraído de uma interpretação sistemática, do seu espírito, deve-se considerar o corpus constitucional que compreende os demais diplomas normativos que estão ladeados com a Constituição nos moldes estatuídos pelo ordenamento constitucional do respectivo Estado, todos os valores e princípios derivados da Constituição e também os costumes constitucionais (secundum constitutionem e praeter constitutionem).

\section{A FUNÇÃO LEGISLATIVA STRICTO SENSU EXER- CIDA PELO TRIBUNAL CONSTITUCIONAL}

O Tribunal Constitucional não deve exercer com exclusividade o controle da constitucionalidade das leis, nem tampouco deve exercer apenas o controle de constitucionalidade das leis, mas sim uma "jurisdição constitucional" ${ }^{51}$

Deve-se ter o cuidado para que o estudo das funções de um Tribunal Constitucional não fique limitado à análise de questões relacionadas com o controle de constitucionalidade das leis. Essa limitação não corresponde à realidade, afinal o Tribunal Constitucional vem de longa data desempenhando outras funções, tão próprias e inerentes ao Tribunal Constitucional como o controle da constitucionalidade das leis em face da Constituição.

Paralelamente ao controle de constitucionalidade das leis, os Tribunais Constitucionais assumiram e vêm desenvolvendo outras relevantes funções constitucionais, podendo-se elencar as seguintes categorias funcionais fundamentais (estruturais ou próprias): $a$ ) interpretativa; $b$ ) estruturante; $c$ ) arbitral; $d$ ) governativa; $e$ ) legislativa stricto sensu; e f) comunitarista, não sendo demais afirmar que tais funções não são excludentes, de modo que, em uma mesma decisão, podem ser manifestadas mais de uma dessas funções. 
O Tribunal Constitucional e o exercício da função legislativa stricto sensu para a efetivação dos direitos fundamentais em decorrência de uma omissão legislativa inconstitucional

O objeto de análise deste artigo é o exercício da função legislativa stricto sensu que decorre de uma inconstitucionalidade por omissão em que se destina verificar a inexistência de espécie legislativa necessária para tornar exequíveis determinados direitos fundamentais, partindo de uma pretensão que se assenta não na existência de enunciados normativos inconstitucionais, mas na violação da Constituição pelo silêncio legislativo (violação por omissão, por inércia) que não deixa ecoar um direito fundamental.

A expressão "função legislativa" pode ser empregada quando outro órgão estatal, que não o Legislativo, edita enunciados normativos gerais (generalidade pelo destinatário - em oposição à individualidade) e abstratos - em oposição ao concreto -, ou seja, com alcance erga omnes.

A função legislativa stricto sensu pode se manifestar por diversas espécies, destacando: $a$ ) competência para elaborar leis; $b$ ) controle preventivo da constitucionalidade; $c$ ) controle das omissões legislativas inconstitucionais; $d$ ) decisões aditivas, redutoras e substitutivas; e) elaboração de seu regimento interno; $f$ ) interpretação conforme; $g$ ) declaração de nulidade sem redução de texto; $h$ ) decisões transitivas. Este estudo se limitará a abordar o exercício da função legislativa stricto sensu no controle das omissões legislativas inconstitucionais.

Naquilo que se está aqui a analisar, a função legislativa stricto sensu, exercida no controle das omissões legislativas inconstitucionais, ocorre quando o Tribunal Constitucional desempenha, temporariamente, função legislativa, a fim de suprir uma lacuna normativa deixada pelo legislador (de qualquer órgão estatal - Legislativo, Executivo, v.g.) e que seja ofensiva à plena eficácia de um direito fundamental, até que esse legislador saia da inércia e exerça a competência da qual é titular.

O exercício da função de controle das omissões inconstitucionais do legislador (e sua solução) implica a realização de uma função tipicamente legislativa, pois se trata de superar uma omissão legislativa inconstitucional decorrente da negatividade (objetivamente falando) do legislador. ${ }^{52}$

A constatação de que a omissão compromete a concretude de determinado direito fundamental é condição sine qua non para que o Tribunal Constitucional atue como órgão dotado de capacidade legislativa stricto sensu superveniente, provisória e específica. 


\section{COMPETÊNCIA TITULAR (ORIGINÁRIA) PARA O EXERCÍCIO DA FUNÇÃO LEGISLATIVA STRICTO SENSUE ASUA SUBSTITUIÇÃO PROVISÓRIA PELO TRIBUNALCONSTITUCIONALNOCONTROLEDAS OMISSÕES LEGISLATIVAS INCONSTITUCIONAIS}

Cumpre aqui trazer algumas considerações acerca da competência titular (originária) para o exercício da função legislativa stricto sensu e a sua substituição pelo Tribunal Constitucional, considerando que essa função é exercida ora pelo órgão constitucional titular (Legislativo), ora por outro órgão constitucional de soberania (Executivo, ${ }^{53}$ outro Legislativo $^{54}$ ou Tribunal Constitucional).

Por competência entende-se o dever-poder de ação e de atuação atribuído a determinado(s) órgão(s) estatal(is), com o fim de prosseguir(em) com as tarefas que lhe são constitucionalmente incumbidas.

A divergência entre as funções do Estado e os órgãos estatais, considerados estes no sentido orgânico, aumenta quando é necessário atribuir a mais de um órgão estatal a competência para o exercício de uma mesma função, como está a acontecer em tantos Estados com a função legislativa.

Canotilho, no âmbito das competências constitucionais, faz a seguinte distinção: competência exclusiva: atribuída a um só órgão; competência concorrente: atribuída, a título igual, a vários órgãos; competência-quadro: atribuída, quanto à definição de bases ou princípios, a um órgão e, quanto à densificação particularizante, a outro. Anota ainda o mestre lusitano que a regra é a da atribuição de competências exclusivas e, no caso de haver competências concorrentes ou competências-quadro, é a própria Constituição que a especifica. ${ }^{55}$

Tavares, com enfoque preciso, leciona que a função legislativa scricto sensu exercida pelo Tribunal Constitucional, quando no controle das omissões legislativas inconstitucionais, deve estar ancorada em uma específica partilha de competência constitucional sucessiva (na omissão do legislador, a competência transfere-se para o Tribunal Constitucional). ${ }^{56}$ 
O Tribunal Constitucional e o exercício da função legislativa stricto sensu para a efetivação dos direitos fundamentais em decorrência de uma omissão legislativa inconstitucional

O Estado contemporâneo reflete uma série de alterações importantes nas relações entre os órgãos constitucionais de soberania, podendo-se afirmar, no que se refere à produção do Direito, que o Legislativo não possui o monopólio de criação de normas com classe de lei. ${ }^{57}$

Como já afirmado, a cláusula da separação de poderes não proíbe o exercício de determinada função (competência), por um órgão constitucional de soberania, de atos, que pela sua natureza essencial, pertençam a outro. Antes, sua correta formulação consiste em afirmar que a um poder é lícito, constitucionalmente, exercer qualquer direito ou faculdade, seja qual for sua íntima natureza, desde que assim o estabeleça a Constituição.

Não se discute que as Constituições atuais atribuíram ao Legislativo, por excelência, a competência originária para o exercício da função legislativa por meio de seu ato típico que é a lei. Mas também não se pode negar que, existindo previsão na Constituição, poderá também o Tribunal Constitucional exercer a função legislativa em substituição ao Legislativo a fim de implementar direitos fundamentais.

É inquestionável que é o Legislativo que detém a competência titular (originária) para legislar. Suas escolhas jurídico-políticas gozam de legitimidade ótima. Contudo, defende-se que o Tribunal Constitucional exerça função legislativa stricto sensu, quando a atuação do Legislativo se mostrar insuficiente ou omissa. Não se está a defender a possibilidade de o Tribunal Constitucional atuar como um legislador positivo (stricto sensu) de forma primeira e original, mas sim em substituição provisória ao titular.

Que fique riscado com pena forte que é o Legislativo o órgão, estrutural e funcionalmente, mais adequado (conforme a evolução e as vicissitudes políticas) para o exercício da função legislativa, afinal, seu papel funda-se, simultaneamente: $a$ ) na ideia (democrática) de que a lei, dirigida a todo o povo, deve ser votada pelos seus representantes eleitos; $b$ ) na ideia (liberal) do debate e do compromisso, em que, se a racionalidade ao cabo não consegue prevalecer, pelo menos é posta a clara luz; e c) na ideia (pluralista) de que uma assembleia representativa de opiniões e interesses diversos é mais apta para tomar as grandes deliberações (legislativas e também políticas) do que qualquer outro órgão constitucional de soberania. ${ }^{58}$ 
Como exposto, as decisões do Tribunal Constitucional, quando oriundas do exercício da função legislativa stricto sensu, devem ser compreendidas como decisões tipicamente derivadas de uma distribuição constitucional de competências, em que cada órgão constitucional de soberania respeite as competências dos demais, inadmitindo-se a ideia de que, com a atuação do Tribunal Constitucional, ocorreria a perda de competência como sanção à inconstitucionalidade por omissão, já que não se está defendendo a perda de competência, mas sim uma substituição provisória da função de legislar.

\section{A NATUREZA JURÍDICA DA FUNÇÃO LEGISLA- TIVA STRICTO SENSU NO CONTROLE DAS OMIS- SÕES LEGISLATIVAS INCONSTITUCIONAIS}

A natureza jurídica das decisões do Tribunal Constitucional, quando no exercício da função legislativa stricto sensu, ombreia-se com a função legislativa exercida comumente pelo Legislativo quando atua como legislador positivo.

Como demonstrado, a atuação do Tribunal Constitucional na função legislativa stricto sensu dá-se tão somente em substituição provisória ao Legislativo titular. Por consequência lógica, o enunciado normativo editado pelo substituto (Tribunal Constitucional) não pode ter natureza jurídica distinta da atuação do substituído (titular) (Legislativo).

Contudo, o fato de o enunciado normativo editado pelo Tribunal Constitucional ter a mesma natureza do enunciado normativo editado pelo Legislativo não permite concluir que a "atividade" exercida pelo Tribunal Constitucional, que é "jurídica", se confunda com a "atividade política" exercida pelo Legislativo, já que a última é uma "atividade mais livre".

Pelo constatado, a atuação do Tribunal Constitucional, na função legislativa stricto sensu, assemelha-se a do legislador ordinário, desde que abstraídas as conveniências políticas da atuação, não podendo assim sua produção legislativa ter natureza jurídica distinta daquela que é inerente ao ato normativo que é editado pelo legislador titular (Legislativo). 
O Tribunal Constitucional e o exercício da função legislativa stricto sensu para a efetivação dos direitos fundamentais em decorrência de uma omissão legislativa inconstitucional

A diferença que se verifica entre a função legislativa implementada pelo Legislativo e a normação positiva editada pelo Tribunal Constitucional é a de que aquele produz enunciados normativos para regular a vida em sociedade com uma maior liberdade de atuação, enquanto o Tribunal Constitucional, quando edita enunciados normativos, o faz exclusivamente com a finalidade de efetivar a Constituição e os direitos fundamentais - este é o motivo-finalidade da atuação do Tribunal Constitucional como órgão constitucional de normação positiva, diferente do Legislativo, ${ }^{59}$ cuja função de legislar não possui por finalidade exclusiva efetivar a Constituição e os direitos fundamentais.

\section{EFICÁCIA ERGA OMNES DA NORMAÇÃO POSITI- VA EDITADA PELO TRIBUNAL CONSTITUCIONAL}

As fontes do direito devem ser identificadas pelas normas do próprio ordenamento jurídico (as normas sobre produção do Direito) que devem estar contidas na respectiva Constituição, consignando que, para a teoria kelseniana, as normas sobre produção e reconhecimento do Direito constituem a essência material da Constituição.

F. Callejón leciona que o essencial, na caracterização de uma fonte do Direito, está em determinar se o enunciado normativo tem capacidade para gerar eficácia erga omnes, ou seja, capacidade para alcançar todos os sujeitos de um ordenamento jurídico. ${ }^{60}$

Como já constatado, o Direito não mais se identifica exclusivamente com a lei, não se podendo assim pretender restringir o caráter geral, impessoal e obrigatório apenas à lei.

Negar a eficácia erga omnes de determinadas decisões do Tribunal Constitucional sob o argumento de que tal eficácia se restringiria às leis é reduzir o conceito de lei à lei formal elaborada pelo Legislativo.

As decisões do Tribunal Constitucional também podem se apresentar como normas de produção jurídica, ou seja, decisões que produzem o Direito ou que interpretam as normas que produzem o Direito.

Como bem acentua Tavares: 
Atualmente, não há como desconsiderar que a decisão proferida em sede de Tribunal Constitucional deva produzir coisa julgada oponível erga omnes, conforme preconiza o modelo austríaco. Isso quer significar, basicamente, que sua eficácia deve estender-se para além das pessoas envolvidas no processo. ${ }^{61}$

Trata-se, então, da eficácia erga omnes de eficácia implícita às decisões de um Tribunal Constitucional quando no desempenho de suas funções, apresentando-se como um pressuposto do processo objetivo.

Assim sendo, a generalidade e a abstração constituem apanágio dos enunciados normativos com eficácia erga omnes, proporcionando assim uma maior inteligibilidade dos seus textos e facilitando a sua aplicação a uma universalidade de situações e/ou de pessoas.

\section{CONCLUSÕES}

Ao longo do artigo, buscou-se imprimir um sentido conclusivo ao que era desenvolvido, contudo é momento de reapresentar as ideias de forma condensada, logo, não exaustiva, com a finalidade de possibilitar uma melhor percepção do que objetivou o presente estudo. É certo também que a temática abordada, por focalizar as esferas jurídica e política, não permite adotar conclusões que sejam indiscutíveis.

De uma vez por todas: a lei não é mais a única e exclusiva fonte do Direito e, assim sendo, não é mais o Legislativo o órgão constitucional de soberania detentor do monopólio da produção normativa.

De igual modo, não mais subsiste o dogma de que o Tribunal Constitucional só poderia atuar como "legislador negativo". Restringir a atuação do Tribunal Constitucional somente a essa espécie de função apenas faria sentido se esse comportamento fosse o único suficiente para a efetivação de direitos fundamentais.

$\mathrm{O}$ argumento de que o Tribunal Constitucional, ao atuar como "legislador positivo", está adentrando na esfera de competência do Legislativo não é mais intenso do que se for utilizado para a atividade de "legislador negativo". Aliás, o Tribunal Constitucional, ao atuar como "legislador negativo", interfere mais no Legislativo do que em sua atuação como "legislador positivo", já que, como "legislador ne- 
O Tribunal Constitucional e o exercício da função legislativa stricto sensu para a efetivação dos direitos fundamentais em decorrência de uma omissão legislativa inconstitucional

gativo", o Tribunal Constitucional se sobrepõe a uma atuação anterior do Legislativo, dizendo que ela está incompatível com a Constituição. Já quando atua como "legislador positivo", nos termos delimitados neste artigo, o Tribunal Constitucional atuará apenas supletivamente, de forma secundária, enquanto o titular não se posicionar de forma comissiva, e não censurando uma escolha do Legislativo.

A atuação do Tribunal Constitucional, em casos de omissão legislativa inconstitucional, está legitimada a ocorrer para o exercício da curadoria dos direitos fundamentais e deverá ter um caráter eminentemente objetivo, devendo o Tribunal Constitucional desconsiderar qualquer vontade subjetiva do legislador e se ater apenas à situação factual da necessidade de se efetivar a Constituição.

Não se pode perder de vista que, nesse tipo de controle de constitucionalidade por omissão, o que justifica o exercício da função legislativa stricto sensu pelo Tribunal Constitucional é a preocupação em eliminar a inconstitucionalidade e, por consequência, efetivar e assegurar o cumprimento dos direitos fundamentais. O que importa essencialmente é colmatar a omissão legislativa inconstitucional que compreende o objeto do controle e assim efetivar (implementar) os direitos fundamentais, ficando para outro plano qualquer análise acerca da (in)consequência da omissão.

Não se está a propugnar que o Tribunal Constitucional seja o melhor ambiente para a edição de atos normativos, de leis, e que o Legislativo não seja a "caixa de ressonância" da sociedade.

Contudo, se essa caixa de ressonância não chega a atingir decibéis hábeis para a edição de uma lei, e essa omissão se mostre inconstitucional, é o momento de alguém fazer valer a Constituição, principalmente quando o que se está em jogo é a efetivação de direitos fundamentais.

Não se pode esquecer que, na maioria das vezes, essas omissões inconstitucionais ofendem normas constitucionais que buscam tutelar direitos fundamentais de uma minoria. Minoria esta que, por vezes, pode não conseguir fazer ecoar seus anseios no Legislativo por não ter aí uma representatividade considerável.

Assim é que a função legislativa stricto sensu a ser exercida pelos Tribunais Constitucionais se apresenta como um instrumento de curadoria dos direitos fundamentais. 
Obviamente, o exercício da função legislativa stricto sensu pelo Tribunal Constitucional importa alguns riscos, mas também não se pode deixar de assumi-los, como justificativa para que este ou aquele direito fundamental não seja otimamente efetivado, e que, caso ocorram excessos e desvios por parte do Tribunal Constitucional, estes pertencerão à classe da patologia política, competindo ao Direito Constitucional indicar, em cada caso, os remédios adequados e sua posologia.

\section{NOTAS}

1 KELSEN, Hans. Teoria geral do direito e do Estado. 3. ed. Tradução de Luís Carlos Borges. São Paulo: Martins Fontes, 2000. p. 390.

2 CANOTILHO, José Joaquim Gomes. Direito constitucional e teoria da Constituição. 4. ed. Coimbra: Almedina, 2000. p. 549. Os órgãos constitucionais de soberania a que alude Canotilho são os órgãos supremos definidos por Silva como aqueles "[...] a quem incumbe o exercício do poder político, cujo conjunto se denomina governo ou órgãos governamentais" (SILVA, José Afonso da. Curso de direito constitucional positivo. 33. ed. rev. e atual. São Paulo: Malheiros, 2010. p. 107).

3 ACKERMAN, Bruce. A nova separação dos poderes. Tradução de Isabelle Maria Campos Vasconcelos e Eliana Valadares Santos. Rio de Janeiro: Lumen Juris, 2009. p. 113; VILE, M. J. C. Constitucionalismo y separación de poderes. 2. ed. Tradução de Xohana Bastida Calvo. Madrid: Centro de Estúdios Políticos y Constitucionales, 2007. p. 391.

4 CORNEJO, Valentin Thury. Juez y division de poderes hoy. Buenos Aires: Ciudad Argentina, 2002. p. 387.

5 CAETANO, Marcello. Manual de ciência política e direito constitucional. 6. ed. rev. e ampl. Coimbra: Almedina, 2003. t. 1. p. 143-148.

6 MALBERG, R. Carré de. Teoría general del Estado. Tradução de José Lión Depetre. 2. ed. México: Fondo de Cultura Económica, 2001. p. 766-770; 779-782. Kelsen também descoloriu a fronteira pretensamente nítida da separação de poderes, entendendo que a clássica teoria só se aplicaria em casos claros e induvidosos, já que a maioria dos atos estatais são, ao mesmo tempo, atos criadores e aplicadores do direito (KELSEN, Hans. Teoria geral do direito e do Estado. 3. ed. Tradução de Luís Carlos Borges. São Paulo: Martins Fontes, 2000. p. 385-386).

7 MALBERG, R. Carré de. Teoría general del Estado. Tradução de José Lión Depetre. 2. ed. México: Fondo de Cultura Económica, 2001. p. 770.

8 DUGUIT, León. La separación de poderes y La Asamblea Nacional de 1789. Tradução de Pablo Pérez Tremps. Madrid: Centro de Estudios Constitucionales, 1996. p. 132.

9 KELSEN, Hans. Teoria geral do direito e do Estado. 3. ed. Tradução de Luís Carlos Borges. São Paulo: Martins Fontes, 2000. p. 402. No mesmo sentido, encontra-se a seguinte lição: “' $A$ separação de poderes' é antes de tudo um princípio de técnica constitucional destinada a evitar o despotismo e a garantir a liberdade" (HAMON, Francis; TROPER, Michel; BURDEAU, Georges. Direito constitucional. 27. ed. Tradução de Carlos Sousa. Barueri: Manole, 2005. p. 87). Não se pode deixar de registrar que essa era a ideia de Montesquieu ao afirmar: "Tudo estaria perdido se o mesmo homem, ou o mesmo corpo dos principais, ou dos nobres, ou do povo exercesse os três poderes: o de fazer as leis, o de executar as resoluções públicas e o de julgar os crimes ou as querelas entre os particulares" (MONTESQUIEU, Charles de Secondat. O espírito das leis. Tradução de Cristina Murachco. São Paulo: Martins Fontes, 2000. p. 168).

10 PIÇARRA, Nuno. A separação dos poderes como doutrina e princípio constitucional. Coimbra: Coimbra Editora, 1989. p. 262. 
O Tribunal Constitucional e o exercício da função legislativa stricto sensu para a efetivação dos direitos fundamentais em decorrência de uma omissão legislativa inconstitucional

11 SILVA, José Afonso da. Curso de direito constitucional positivo. 33. ed. rev. e atual. São Paulo: Malheiros, 2010. p. 45.

12 ENTERRÍA, Eduardo García. La Constitución como norma y el Tribunal Constitucional. 4. ed. Madrid: Civitas, 2006. p. 69-100.

13 HESSE, Konrad. A força normativa da Constituição. Tradução de Gilmar Ferreira Mendes. Porto Alegre: Sergio Antonio Fabris, 1991.

14 LLORENTE, Francisco Rubio. La forma del poder: estudios sobre la Constitución. Madrid: Centro de Estudios Constitucionales, 1993. p. 97.

15 CANOTILHO, José Joaquim Gomes. Direito constitucional e teoria da Constituição. 4. ed. Coimbra: Almedina, 2000. p. 1115.

16 CAMPOS, German Bidart. El derecho de la Constitución y su fuerza normativa. Buenos Aires: Ediar, 2004. p. 65.

17 HESSE, Konrad. A força normativa da Constituição. Tradução de Gilmar Ferreira Mendes. Porto Alegre: Sergio Antonio Fabris, 1991. p. 15.

18 ROCHA, Carmem Lúcia Antunes. O princípio constitucional da igualdade. Belo Horizonte: Lê, 1990. p. 12.

19 BARROSO, Luís Roberto. O direito constitucional e a efetividade de suas normas. 9. ed. rev. e atual. Rio de Janeiro: Renovar, 2009. p. 60.

20 HÄBERLE, Peter. El Estado constitucional. Tradução de Héctor Fix-Fierro. Buenos Aires: Astrea, 2007. p. 230.

21 ALEXY, Robert. Direitos fundamentais no Estado constitucional democrático: para a relação entre direitos do homem, direitos fundamentais, democracia e jurisdição constitucional. Tradução de Luís Afonso Heck. Revista de Direito Administrativo, Rio de Janeiro, v. 217, p. 55-66, jul./set. 1999. p. 63.

22 LOEWENSTEIN, Karl. Teoría de la Constitución. Tradução de Alfredo Gallego Anabitarte. 2. ed. Barcelona: Ariel, 1979. p. 149.

23 A terminologia "curadoria" procura conjugar as ideias fundamentais de ser além de um defensor da Constituição, mas também um implementador da Constituição (realizando-a, aplicando-a, efetivando-a ou exigindo seu cumprimento). (Cf. a esse respeito: TAVARES, André Ramos. Teoria da justiça constitucional. São Paulo: Saraiva, 2005. p. 71-102).

24 CAMPOS, German Bidart. El derecho de la Constitución y su fuerza normativa. Buenos Aires: Ediar, 2004. p. 173.

25 SAMPAIO, José Adércio Leite. A Constituição reinventada pela jurisdição constitucional. Belo Horizonte: Del Rey, 2002. p. 550.

26 CLÈVE, Clèmerson Merlin. Fiscalização abstrata da constitucionalidade no direito brasileiro. 2. ed. São Paulo: Revista dos Tribunais, 2000. p. 34-35.

27 SOSPEDRA, Manuel Martínez. Manual de derecho constitucional: parte general. Valencia: Tirant lo Blanch, 2007. p. 196-197.

28 O Conselho Constitucional francês, em 1971, decidiu que o preâmbulo da Constituição francesa, bem como qualquer outro documento ou princípio mencionado pelo preâmbulo faziam parte do "bloc de constitucionalité", isto é, da Constituição, e que tais eram elementos constitutivos da Constituição (TROPER, Michel. Interpretação constitucional. Tradução de Pedro Buck. Revista Brasileira de Estudos Constitucionais - RBEC, Belo Horizonte, v. 2, n. 7, p. 53-70, jul./set. 2008. p. 68).

29 LLORENTE, Francisco Rubio. La forma del poder: estudios sobre la Constitución. Madrid: Centro de Estudios Constitucionales, 1993. p. 99-100.

30 AGRA, Walber de Moura. Aspectos controvertidos do controle de constitucionalidade. Salvador: Juspodivm, 2008. p. 171.

31 CANOTILHO, José Joaquim Gomes. Direito constitucional e teoria da Constituição. 4. ed. Coimbra: Almedina, 2000. p. 215.

32 " $\$ 3^{\circ}$ Os tratados e convenções internacionais sobre direitos humanos que forem aprovados, em cada Casa do Congresso Nacional, em dois turnos, por três quintos dos votos dos respectivos membros, serão equivalentes às emendas constitucionais."

33 PIOVESAN, Flávia. Direitos humanos e o direito constitucional internacional. 4. ed. São Paulo: Max Limonad, 2000. p. 92-93. No mesmo sentido: MENDES, Gilmar Ferreira. 
Jurisdição constitucional: o controle abstrato de normas no Brasil e na Alemanha. 5. ed. São Paulo: Saraiva, 2005. p. 239.

34 CONI, Luís Cláudio. A internacionalização do poder constituinte. Porto Alegre: Sergio Antonio Fabris, 2006. p. 94. Continua o autor: "Esse, talvez, seja o papel do intérprete da Constituição: ao ponderar, de maneira extrovertida, sobre o locus mais adequado para a máxima efetividade dos dispositivos constitucionais que deseja ser assegurados [...]" (Ibidem, p. 96).

35 MENDES, Gilmar Ferreira. Jurisdição constitucional: o controle abstrato de normas no Brasil e na Alemanha. 5. ed. São Paulo: Saraiva, 2005. p. 136.

36 BITTENCOURT. C. A. Lúcio. O contrôle jurisdicional da constitucionalidade das leis. Rio de Janeiro: Forense, 1949. p. 54-55.

37 FERRAZ, Anna Cândida da Cunha. Processos informais de mudança da Constituição: mutações constitucionais e mutações inconstitucionais. São Paulo: Max Limonad, 1986. p. 22

38 CAVALCANTI, Themistocles Brandão. Do contrôle da constitucionalidade. Rio de Janeiro: Forense, 1966. p. 73. Em idêntico sentido afirma Maximiliano que o "[...] espírito da lei suprema pode ser invocado sòmente como incluído na letra de um dispositivo, e não para se pronunciarem inconstitucionalidades não previstas pelo texto" (MAXIMILIANO, Carlos. Comentários à Constituição brasileira. 5. ed. atual. São Paulo: Freitas Bastos, 1954. v. 1. p. 134).

39 TEIXEIRA, José Horácio Meirelles. Curso de direito constitucional. Rio de Janeiro: Forense Universitária, 1991. p. 149. No item 3.2.3, verificar-se-á a possibilidade de influência da função enunciativa nos costumes constitucionais, e no item 4.6.1, o costume constitucional será demonstrado como limite da atuação do Tribunal Constitucional como órgão de normação positiva.

40 CAMPOS, German Bidart. El derecho de la Constitución y su fuerza normativa. Buenos Aires: Ediar, 2004. p. 203.

41 GARCIA-PELAYO, Manuel. Derecho constitucional comparado. 3. ed. Madrid: Revista de Occidente, 1953. p. 136.

42 VIGO, Rodolfo Luis. Interpretación constitucional. 2. ed. Buenos Aires: Lexis Nexis/ Abeledo-Perrot, 2004. p. 57.

43 MIRANDA, Jorge. Manual de direito constitucional. 5. ed. rev. e actual. Coimbra: Coimbra Editora, 2003. t. 2. p. 139.

44 HELLER, Hermann. Teoria do Estado. Tradução Lycurgo Gomes da Motta. São Paulo: Mestre Jou, 1968. p. 296 e 298. Continua o autor: "Só se valora positivamente e, por conseguinte, se converte em normatividade aquela normalidade a respeito da qual se crê que é uma regra empírica da existência real, uma condição de existência ora da humanidade em geral, ora de um grupo humano" (Ibidem, p. 298).

45 HAMON, Francis; TROPER, Michel; BURDEAU, Georges. Direito constitucional. 27. ed. Tradução de Carlos Sousa. Barueri: Manole, 2005. p. 50.

46 Canotilho traz que "[...] as constituições em geral, não fazem qualquer referência ao costume como modo de produção jurídica, [e] o costume deve ser considerado não como um instrumento da criação de uma regra, mas como um meio de prova da existência dessa regra" (CANOTILHO, José Joaquim Gomes. Direito constitucional e teoria da Constituição. 4. ed. Coimbra: Almedina, 2000. p. 834-835).

47 GUASTINI, Riccardo. Estudios de teoría constitucional. Tradução de Miguel Carbonell. Cidade do México: Fontamara, 2001. p. 253.

48 CANOTILHO, José Joaquim Gomes. Direito constitucional e teoria da Constituição. 4. ed. Coimbra: Almedina, 2000. p. 1099-1100.

49 CANOTILHO, José Joaquim Gomes. Direito constitucional e teoria da Constituição. 4. ed. Coimbra: Almedina, 2000. p. 1100-1101. Canotilho considera como “[...] corpus constitucional o conjunto limitado de materiais normativos que formam a constituição" (Ibidem, p. 1096).

50 FERRAZ, Anna Cândida da Cunha. Processos informais de mudança da Constituição: mutações constitucionais e mutações inconstitucionais. São Paulo: Max Limonad, 1986. p. 183-184. Para Quintana, a aceitação dos costumes só é possível num regime de Constituição flexível e consuetudinária (QUINTANA, Segundo V. Linares. Tratado de interpretacíon constitucional. 2. ed. Buenos Aires: Abeledo Perrot, 2008. t. 1. p. 711). 
51 Destaca Tavares que é “[...] comum o emprego da expressão 'jurisdição constitucional' para designar a sindicabilidade desenvolvida judicialmente tendo por parâmetro, a Constituição e por hipótese de cabimento o comportamento em geral e, principalmente, do Poder Público, contrário àquela norma paramétrica" (TAVARES, André Ramos. Curso de direito constitucional. 7. ed. rev. e ampl. São Paulo: Saraiva, 2009. p. 242). Consigna o mesmo autor que "[...] não há consenso sobre o alcance das expressões 'Justiça Constitucional', 'jurisdição constitucional' ou mesmo 'Tribunal Constitucional' [...]." (TAVARES, André Ramos. Teoria da justiça constitucional. São Paulo: Saraiva, 2005. p. 141).

52 As omissões legislativas inconstitucionais não se confundem com as lacunas constitucionais. Àquelas “[...] correspondem a normas constitucionais não exeqüíveis por si mesmas e cujo não preenchimento (ou não preenchimento após o decurso de certo tempo) determina inconstitucionalidade por omissão", já as lacunas são situações constitucionalmente relevantes mas não previstas (MIRANDA, Jorge. Manual de direito constitucional. 5. ed. rev. e actual. Coimbra: Coimbra Editora, 2003. t. 2. p. 303).

53 Em várias Constituições, o chefe do Poder Executivo encontra-se autorizado a editar atos cuja competência originária é do Legislativo, desde que verificadas circunstâncias específicas, tais como: urgência e relevância. V.g., aqui, no Brasil, as medidas provisórias (art. 59, $\mathrm{V} \mathrm{c/c} \mathrm{o} \mathrm{art.} \mathrm{62,} \mathrm{ambos} \mathrm{da} \mathrm{CRFB)} \mathrm{e} \mathrm{na} \mathrm{Itália} \mathrm{o} \mathrm{decreti-legge} \mathrm{(art.} 77$ da Constituição italiana).

54 Algumas Constituições prescrevem a possibilidade de outro órgão legislativo atuar no lugar do titular enquanto o órgão titular se mantenha inerte. A CRFB trouxe, no art. 24, $\S 3^{\circ}$, um deslocamento de competências no contexto da federação ao possibilitar que os Estados federados exerçam a competência legislativa plena (com relação à competência concorrente) para atender às suas peculiaridades enquanto a União não houver exercido sua competência genérica.

55 CANOTILHO, José Joaquim Gomes. Direito constitucional e teoria da Constituição. 4. ed. Coimbra: Almedina, 2000. p. 533.

56 TAVARES, André Ramos. Teoria da justiça constitucional. São Paulo: Saraiva, 2005. p. 327.

57 VERDÚ, Pablo Lucas; CUEVA, Pablo Lucas Murillo de la. Manual de derecho politico. 3. ed. Madrid: Tecnos, 2005. p. 80.

58 MIRANDA, Jorge. Manual de direito constitucional. 3. ed. Coimbra: Coimbra Editora, 2004. t. 5. p. 155

59 TAVARES, André Ramos. Teoria da justiça constitucional. São Paulo: Saraiva, 2005. p. 188.

60 CALLEJÓN, Francisco Balaguer. Fuentes de derecho: I. principios del ordenamiento constitucional. Madrid: Tecnos, 1991. p. 65.

61 TAVARES, André Ramos. Teoria da justiça constitucional. São Paulo: Saraiva, 2005. p. 440.

\section{REFERÊNCIAS}

ACKERMAN, Bruce. A nova separação dos poderes. Tradução de Isabelle Maria Campos Vasconcelos e Eliana Valadares Santos. Rio de Janeiro: Lumen Juris, 2009.

\section{AGRA, Walber de Moura. Aspectos controvertidos do controle de constitucionalidade. Salvador: Juspodivm, 2008.}

ALEXY, Robert. Direitos fundamentais no Estado constitucional
democrático: para a relação entre direitos do homem, direitos fun-
damentais, democracia e jurisdição constitucional. Tradução de Luís 
Afonso Heck. Revista de Direito Administrativo, Rio de Janeiro, v. 217, p. 55-66, jul./set. 1999.

BACHOF, Otto. Normas constitucionais inconstitucionais? Tradução de José Manuel M. Cardoso da Costa. Coimbra: Almedina, 1994.

BARROSO, Luís Roberto. O direito constitucional e a efetividade de suas normas. 9. ed. rev. e atual. Rio de Janeiro: Renovar, 2009.

BASTOS, Celso Ribeiro. Hermenêutica e interpretação constitucional. São Paulo: Celso Bastos, 1997.

BITTENCOURT. C. A. Lúcio. O contrôle jurisdicional da constitucionalidade das leis. Rio de Janeiro: Forense, 1949.

BRASIL. Supremo Tribunal Federal. Pleno. MI 712/PA. Relator: ministro Eros Grau. Diário da Justiça Eletrônico, Brasília, DF, 30 out. 2008.

BRASIL. Supremo Tribunal Federal. Pleno. MI 670/ES. Relator para acórdão: ministro Gilmar Mendes. Diário da Justiça Eletrônico, Brasília, DF, 30 out. 2008.

CAETANO, Marcello. Manual de ciência política e direito constitucional. 6. ed. rev. e ampl. Coimbra: Almedina, 2003. t. 1.

CALLEJÓN, Francisco Balaguer. Fuentes de derecho: I. principios del ordenamiento constitucional. Madrid: Tecnos, 1991.

CAMPOS, German Bidart. El derecho de la Constitución y su fuerza normativa. Buenos Aires: Ediar, 2004.

CANOTILHO, José Joaquim Gomes. Direito constitucional e teoria da Constituição. 4. ed. Coimbra: Almedina, 2000.

CAPPELLETTI, Mauro. Juízes legisladores? Tradução de Carlos Alberto Alvaro de Oliveira. Porto Alegre: Sergio Antonio Fabris, 1999.

CAVALCANTI, Themistocles Brandão. Do contrôle da constitucionalidade. Rio de Janeiro: Forense, 1966. 
O Tribunal Constitucional e o exercício da função legislativa stricto sensu para a efetivação dos direitos fundamentais em decorrência de uma omissão legislativa inconstitucional

CLÈVE, Clèmerson Merlin. Fiscalização abstrata da constitucionalidade no direito brasileiro. 2. ed. São Paulo: Revista dos Tribunais, 2000.

CONI, Luís Cláudio. A internacionalização do poder constituinte. Porto Alegre: Sergio Antonio Fabris, 2006.

CORNEJO, Valentin Thury. Juez y division de poderes hoy. Buenos Aires: Ciudad Argentina, 2002.

DIMOULIS, Dimitri. Significado e atualidade da separação de poderes. In: AGRA, Walber de Moura; CASTRO, Celso Luiz Braga de; TAVARES, André Ramos (Coord.). Constitucionalismo: os desafios no terceiro milênio. Belo Horizonte: Fórum, 2008. p. 143-161.

DUGUIT, Léon. La separación de poderes y la Asamblea Nacional de 1789. Tradução de Pablo Pérez Tremps. Madrid: Centro de Estudios Constitucionales, 1996.

ECHAVARRÍA, Juan José Solozábal. Apresentação da obra. In: ROSA, André Vicente Pires. Las omisiones legislativas y su control constitucional. Rio de Janeiro: Renovar, 2006.

ENTERRÍA, Eduardo García. La Constitución como norma y el Tribunal Constitucional. 4. ed. Madrid: Civitas, 2006.

FAVOREU, Louis. Ponencia francesa. Tradução de Emilio Calderón Martín. In: FAVOREU, Louis; LLORENTE, Francisco Rubio. El bloque de la contitucionalidad: simposium franco-español de derecho constitucional. Madrid: Civitas, 1991.

FERRAZ, Anna Cândida da Cunha. Conflito entre poderes: o poder congressual de sustar atos normativos do Poder Executivo. São Paulo: Revista dosTribunais, 1994.

. Processos informais de mudança da Constituição: mutações constitucionais e mutações inconstitucionais. São Paulo: Max Limonad, 1986.

FERRAZ JR., Tercio Sampaio. O Judiciário frente à divisão dos poderes: um princípio em decadência? Revista Trimestral de Direito Público, São Paulo, Malheiros, n. 9, p. 40-48, 1995. 
FERREIRA FILHO, Manoel Gonçalves. Princípios fundamentais do direito constitucional. São Paulo: Saraiva, 2009.

FIGUEIREDO, Marcelo. O mandado de injunção e a inconstitucionalidade por omissão. São Paulo: Revista dos Tribunais, 1991.

FREITAS, Juarez. O intérprete e o poder de dar vida à Constituição: preceitos de exegese constitucional. In: GUERRA FILHO, Willis Santiago; GRAU, Eros Roberto (Org.). Direito constitucional: estudos em homenagem a Paulo Bonavides. São Paulo: Malheiros, 2001. p. 226-248.

GARCIA-PELAYO, Manuel. Derecho constitucional comparado. 3. ed. Madrid: Revista de Occidente, 1953.

GUASTINI, Riccardo. Das fontes às normas. Tradução de Edison Bini. São Paulo: Quartier Latin, 2005.

Estudios de teoría constitucional. Tradução de Miguel Carbonell. Cidade do México: Fontamara, 2001.

HÄBERLE, Peter. El Estado constitucional. Tradução de Héctor FixFierro. Buenos Aires: Astrea, 2007.

HAMON, Francis; TROPER, Michel; BURDEAU, Georges. Direito constitucional. 27. ed. Tradução de Carlos Sousa. Barueri: Manole, 2005.

HELLER, Hermann. Teoria do Estado. Tradução de Lycurgo Gomes da Motta. São Paulo: Mestre Jou, 1968.

HESSE, Konrad. A força normativa da Constituição. Tradução de Gilmar Ferreira Mendes. Porto Alegre: Sergio Antonio Fabris, 1991.

JELLINEK, Georg. Reforma y mutación de la Constitución. Tradução de Christian Förster. Madrid: Centro de Estudios Constitucionales, 1991.

KELSEN, Hans. Jurisdição constitucional. Tradução de Alexandre Krug, Eduardo Brandão e Maria Ermantina Galvão. São Paulo: Martins Fontes, 2003. 
O Tribunal Constitucional e o exercício da função legislativa stricto sensu para a efetivação dos direitos fundamentais em decorrência de uma omissão legislativa inconstitucional

Teoria geral do direito e do Estado. 3. ed. Tradução de Luís

Carlos Borges. São Paulo: Martins Fontes, 2000.

LLORENTE, Francisco Rubio. La forma del poder: estudios sobre la Constitución. Madrid: Centro de Estudios Constitucionales, 1993.

LOEWENSTEIN, Karl. Teoría de la Constitución. Tradução de Alfredo Gallego Anabitarte. 2. ed. Barcelona: Ariel, 1979.

LUÑO, Antonio Enrique Pérez. Derechos humanos, Estado de derecho y Constitución. 9. ed. Madrid: Tecnos, 2005.

MALBERG, R. Carré de. Teoría general del Estado. Tradução de José Lión Depetre. 2. ed. México: Fondo de Cultura Económica, 2001.

MAXIMILIANO, Carlos. Comentários à Constituição brasileira. 5 . ed. atual. São Paulo: Freitas Bastos, 1954. v. 1.

Hermenêutica e aplicação do direito. 19. ed. Rio de Janeiro: Forense, 2001.

MENDES, Gilmar Ferreira. Direitos fundamentais e controle de constitucionalidade: estudos de direito constitucional. 3. ed. rev. e ampl. São Paulo: Saraiva, 2004.

Jurisdição constitucional: o controle abstrato de normas no Brasil e na Alemanha. 5. ed. São Paulo: Saraiva, 2005.

MIRANDA, Jorge. Manual de direito constitucional. 5. ed. rev. e actual. Coimbra: Coimbra Editora, 2003. t. 2.

Manual de direito constitucional. 3. ed. Coimbra: Coimbra Editora, 2004. t. 5.

MONTESQUIEU, Charles de Secondat. O espírito das leis. Tradução de Cristina Murachco. São Paulo: Martins Fontes, 2000.

MÜLLER, Friedrich. Métodos de trabalho de direito constitucional. 2. ed. rev. Tradução de Peter Naumann. São Paulo: Max Limonad, 2000. 
PEDRA, Anderson Sant'Ana. A constitucionalização do direito administrativo e o controle do mérito do ato administrativo. In: AGRA, Walber de Moura; CASTRO, Celso Luiz Braga de; TAVARES, André Ramos (Coord.). Constitucionalismo: os desafios no terceiro milênio. Belo Horizonte: Fórum, 2008. p. 41-82.

(Im)possibilidade do controle de constitucionalidade pelos Tribunais de Contas: uma análise da súmula n. 347 do STF. In: ABELHA, Marcelo; JORGE, Flávio Cheim (Coord.). Direito processual e administração pública. Rio de Janeiro: Forense Universitária, 2010. p. 17-50.

O controle da proporcionalidade dos atos legislativos: a hermenêutica constitucional como instrumento. Belo Horizonte: Del Rey, 2006.

PIÇARRA, Nuno. A separação dos poderes como doutrina e princípio constitucional. Coimbra: Coimbra Editora, 1989.

PIOVESAN, Flávia. Direitos humanos e o direito constitucional internacional. 7. ed. São Paulo: Saraiva, 2007.

Proteção judicial contra omissões legislativas: ação direta de inconstitucionalidade por omissão e mandado de injunção. 2. ed. rev., atual. e ampl. São Paulo: Revista dos Tribunais, 2003.

QUEIROZ, Cristina. Direito constitucional: as instituições do Estado democrático e constitucional. São Paulo: Revista dos Tribunais; Coimbra: Coimbra Editora, 2009.

QUINTANA, Segundo V. Linares. Tratado de interpretacíon constitucional. 2. ed. Buenos Aires: Abeledo Perrot, 2008. t. 1.

RÁO, Vicente. O direito e a vida dos direitos. 5. ed. anot. e atual. São Paulo: Revista dos Tribunais, 1999.

ROCHA, Cármem Lúcia Antunes. O princípio constitucional da igualdade. Belo Horizonte: Lê, 1990.

ROSA, André Vicente Pires. Las omisiones legislativas y su control constitucional. Rio de Janeiro: Renovar, 2006.

254 Revista de Direitos e Garantias Fundamentais, Vitória, n. 11, p. 222-256, jan./jun. 2012 
O Tribunal Constitucional e o exercício da função legislativa stricto sensu para a efetivação dos direitos fundamentais em decorrência de uma omissão legislativa inconstitucional

ROTHENBURG, Walter Claudius. Inconstitucionalidade por omissão e troca de sujeito: a perda de competência como sanção à inconstitucionalidade por omissão. São Paulo: Revista dos Tribunais, 2005.

RUFFIA, Paolo Biscaretti di. Direito constitucional: instituições de direito público. Tradução de Maria Helena Diniz. São Paulo: Revista dos Tribunais, 1984.

SAMPAIO, José Adércio Leite. A Constituição reinventada pela jurisdição constitucional. Belo Horizonte: Del Rey, 2002.

SILVA, José Afonso da. Curso de direito constitucional positivo. 33. ed. rev. e atual. São Paulo: Malheiros, 2010.

SOSPEDRA, Manuel Martínez. Manual de derecho constitucional: parte general. Valencia: Tirant lo Blanch, 2007.

STERN, Klaus. Derecho del Estado de la Republica Federal Alemana. Tradução de Javier Pérez Royo y Pedro Cruz Villalón. Madrid: Centro de Estudios Constitucionales, 1987.

TAVARES, André Ramos. Curso de direito constitucional. 7. ed. rev. e ampl. São Paulo: Saraiva, 2009.

Teoria da justiça constitucional. São Paulo: Saraiva, 2005.

TEIXEIRA, José Horácio Meirelles. Curso de direito constitucional. Rio de Janeiro: Forense Universitária, 1991.

TROPER, Michel. Interpretação constitucional. Tradução de Pedro Buck. Revista Brasileira de Estudos Constitucionais - RBEC, Belo Horizonte, v. 2, n. 7, p. 53-70, jul./ set. 2008.

VALLE, Vanice Regina Lírio do. Sindicar a omissão legislativa: real desafio à harmonia entre os poderes. Belo Horizonte: Fórum, 2007.

VEGA, Pedro de. La reforma constitucional y la problematica del poder constituyente. Madrid: Tecnos, 1999. 
VERDÚ, Pablo Lucas; CUEVA, Pablo Lucas Murillo de la. Manual de derecho politico. 3. ed. Madrid: Tecnos, 2005.

VIGO, Rodolfo Luis. Interpretación constitucional. 2. ed. Buenos Aires: Lexis Nexis/ Abeledo-Perrot, 2004.

VILE, M. J. C. Constitucionalismo y separación de poderes. 2. ed. Tradução de Xohana Bastida Calvo. Madrid: Centro de Estúdios Políticos y Constitucionales, 2007.

WALDRON, Jeremy. A dignidade da legislação. Tradução de Luís Carlos Borges. São Paulo: Malheiros, 2003.

Artigo recebido em: 23-12-2011

Aprovado em: 15-5-2012 